\title{
LIFE CYCLE ASSESSMENT OF BIOMASS DENSIFICATION SYSTEMS
}

\section{Authors: Rukayya Ibrahim Muazu, Aiduan Li Borrion and Julia A. Stegemann}

Institution for authors

Centre for Resource Efficiency \& the Environment, Department of Civil, Environmental \& Geomatic Engineering, University College London, United Kingdom

email: rukayya.ibrahim.11@ucl.ac.uk

email: a.borrion@ucl.ac.uk

email: j.stegemann@ucl.ac.uk

Corresponding author:

Rukayya Ibrahim Muazu

Department of Civil, Environmental and Geomatic Engineering, University College London

Chadwick building, Gower Street, London, WC1E 6BT

mobile: $+44(0) 7531697254$

\begin{abstract}
Several recent life cycle assessments (LCA) of biomass densification have been carried out. This paper reviews data from 19 sources with 48 case scenarios to assess the current status of LCA of biomass densification. It describes the specific units in a reference "gate-to-gate" LCA in relation to the existing studies, and summarises key differences between them. Finally, it provides a qualitative analysis of the associated sources of uncertainty.
\end{abstract}

Existing LCA studies of biomass densification were found to provide insufficient and inconsistent information for full transparency and comparability, due to different choices in system boundary, functional unit, allocation procedure, densification technology and biomass residues. Most of the reviewed studies attributed most of the energy use and greenhouse gas (GHG) emissions to transportation, drying and densification. The energy and GHG emissions of the gate-to-gate densification system were highly sensitive to the technology, feed material used in densification and scale of production.

Apart from one study with zero energy consumption as a result of the use of manual operations, the normalised values of energy consumption for the reviewed studies ranged from 20 to 900 $\mathrm{kJ} \mathrm{MJ}^{-1}$. Neglecting three outlier values, $\mathrm{GHG}$ emissions as mass of $\mathrm{CO}_{2}$-eq for the reviewed studies ranged from $600 \mathrm{t} \mathrm{MJ}^{-1}$ to $50 \mathrm{~g} \mathrm{MJ}^{-1}$. Similar variations in result and outlier cases have 
been reported for other bioenergy processes, by other authors. Assuming that the biggest impact of densification processes is on transport fuel use, and based on 5 studies that reported densification ratios, the net energy and GHG emissions savings resulting from densification ranged from 200 to $1000 \mathrm{~kJ} \mathrm{MJ}^{-1}$ and 9 to $50 \mathrm{CO}_{2}$-eq $\left(\mathrm{g} \mathrm{MJ}^{-1}\right)$, respectively. On this basis, it can be concluded that biomass densification is a worthwhile addition to the biomass energy conversion system.

There is a need for more transparent reporting and analysis of uncertainty in the modelling, to better understand the wide variation in outcomes.

Keywords: Densification; LCA; Biomass; Energy; $G H G$

\section{Introduction}

Briquetting and pelleting are the two main and most common forms of biomass densification. They have similar process components and production stages but vary in product (densified biomass) sizes, with larger diameter products (e.g., $40 \mathrm{~mm}$ ) generally called briquettes and smaller diameter (e.g., $10 \mathrm{~mm}$ ) products called pellets [e.g.,1,2].

The aim of densification of loose biomass into briquettes or pellets is to increase the energy density, resulting in several benefits, such as reduced transportation costs and storage space requirements, as well as more uniform feeding into conversion equipment [1]. However, the sustainability of biomass densification also depends on the energy consumption, emissions and cost associated with densification itself, and application of the densified biomass, e.g., in combustion or gasification [e.g., 3]. One way to examine the overall sustainability of densification is by LCA. LCA is an environmental management tool that examines the environmental impact of a product, process or service over its entire life cycle, "from cradle to grave" $[4,5]$. The use of LCA in the field of bioenergy has rapidly increased in recent years due to concerns about environmental impacts associated with bioenergy systems, e.g., biodiesel, ethanol and bio-oil [e.g., 6].

Unlike other bioenergy carriers such as ethanol [e.g.,7,8], biodiesel [e.g., 8,9], and heat and electricity generation [10,11], assessment of life cycle environmental impacts associated with biomass fuel briquettes or pellets is still relatively rare. 
This paper reviews the current status of LCA of biomass densification. It describes the specific operations involved in a reference "gate-to-gate" LCA of biomass densification, summarises previous work, and provides a qualitative analysis of the sources of variation and uncertainty associated with the LCA of biomass fuel densification, to guide other future studies.

\section{Life cycle components for biomass densification}

\subsection{Biomass densification system boundary}

A full cradle-to-grave LCA of biomass densification starts from biomass cultivation and ends with disposal of the waste (ash and plant facilities) from briquette/pellet conversion to energy (Figure 1), including environmental impacts that are embodied in the capital equipment, as well as operational environmental impacts. Since densified biomass is mostly produced from agricultural residues such as straws, husks, stalks, leaves and wood wastes, some LCA's define a system boundary that starts at the farm gate, i.e., omitting the processes that result in residue production [e.g., 12]. A reference "gate-to-gate" system boundary for the biomass densification by itself can be defined as from the densification plant entry gate (B in Figure 1), through the densification plant, to its shipping gate ( $\mathrm{C}$ in Figure 1). In some cases, the start gate is defined as the farm or biomass source gate (A) which includes transportation of loose biomass from source to the densification plant entry gate (B), while the end gate can include distribution of densified biomass from the shipping gate (C) to the consumer's or conversion site's gate (D) (Figure 1). Arguably, biomass densification has impacts on conversion of biomass to fuel or energy, which is therefore part of the full life cycle of densified biomass, but the complexities are such that this aspect has not been included in LCA of biomass densification in the literature, and biomass conversion has been simplified as a single box outside the system boundary in Figure 1. The reference "gate-to-gate" biomass densification system (indicated by the red line in Figure 1) thus consists of subsystems including raw biomass storage, drying, size reduction, mixing (in the case of binders or multiple feed biomass), conveying, densification, curing/cooling, screening, packaging, and storage prior to shipping from the briquetting plant gate. The specific components of a biomass densification system affect its life cycle environmental impacts, yet only a few studies provided information on the contributions of specific components to the LCA results. The available information is shown in Table 1, and is discussed in the following sections, including all the components of the reference "gate-togate" system as well as transportation. 


\subsection{Specific units in a gate-to-gate LCA of biomass densification system}

\subsubsection{Feed biomass and/or densified biomass storage}

The loose biomass to be densified and/or the densified biomass may be stored in an open area or buildings (such as silos, warehouses and storage rooms), where the latter prevent losses due to weather and/or animals but are associated with embodied environmental impacts. Some literature studies on LCA of biomass densification showed that the storage unit contributes less than $3 \%$ of the total energy and $2 \%$ of the GHG emissions (Table 1). However, Rousset et al, [21] showed that the storage unit contributes $14 \%$ of the total GHG emissions of the densification system, as a result of additional energy requirement for onsite storage of starch binder. Densified biomass fuel takes less space than loose biomass, with the improvement in storage efficiency depending on the increase in bulk density achieved.

\subsubsection{Drying}

Biomass residues can sometimes be collected with a suitable moisture range for densification [22], as a result of air drying and exposure to sunshine at farm sites. However, some biomass has as high as $70 \%$ moisture content on a wet basis [18] and must be dried to 8 to $10 \%$ for densification [23]. Drying is energy intensive and could make a significant contribution to the overall energy use [e.g., 17,18] and GHG emissions [e.g., 13] (Table 1), depending on the amount of moisture to be removed. The type of dryer (e.g., hot air or superheated steam), capacity, temperature and residence time of the biomass will also affect the environmental impacts of drying [e.g., 24]. For example, a rapid increase in temperature can result in higher emissions of volatile organic carbon during the drying process [25].

\subsubsection{Size reduction}

Most densification systems include a size reduction stage where biomass is chopped, crushed, or ground using equipment such as a crusher or hammer mill [e.g.,26,27]. Size reduction enables more rapid drying of loose feed biomass to be densified [28], and improves compaction. The energy and emissions associated with size reduction depend on the extent of size reduction required, which is greatly influenced by the type of feed biomass and its morphology [e.g., 22,29]. 


\subsubsection{Conveying systems}

In most biomass fuel densification systems, loose biomass and densified biomass are mainly transported through conveying systems, including screw and belt conveyors. The density, particle size and abrasiveness of the biomass to be conveyed affect the design of the conveyor and the quantity of biomass residues conveyed in a given time, which influences the operational hours required, the number of conveyors needed, and the life cycle environmental impacts [e.g., 30, Muazu et al, manuscript in review]. However, the environmental impacts of the conveying system on its own are not very well understood, as most LCA studies count the impact of the conveyor unit as part of the unit to which the feed is conveyed. For example, some densification machines have built-in conveyors. As such, only one of the few studies reported in Table 1 showed the impact of conveying systems.

\subsubsection{Blending}

Most fuel densification systems do not use a separate mixing unit; some [e.g., 21] used the screw conveyor for mixing. In multiple biomass densification, or where binders are added, a separate mixer (e.g., tumble, double cone, or screw) may be required for production of a homogenous feed to the densification unit, which will have an additional energy requirement, dependent on the type and proportion of different materials in the feed mixture.

\subsubsection{Densification (briquetting/pelleting)}

Biomass densification into pellets and briquettes involves the use of equipment such as a pellet mill or briquette press (screw and piston). Pellets, being smaller, are commonly produced by extrusion, whereas larger briquettes are produced by compaction. Pellet mills consist of a perforated die plate with one or two attached rollers. The loose biomass is discharged onto the surface of the plate and forced through the perforations by rotating the die and rollers, to form densified pellets [e.g., 1,28]. Pellet mills are characterised by an ease of operation that permits a high production capacity, but have a high energy requirement. Pellets have a wider industrial application (e.g., co-firing with coal) as a result of their smaller particle size.

Briquette presses include hydraulic or mechanical piston and screw presses, using either an oscillating piston or tapered screw to compact and then release, or extrude, briquettes, respectively [e.g., 1,23]. The screw press was found to consume more energy than the piston 
press [23], which can be attributed to the high energy required for extrusion compared with only compaction [e.g., 1$]$.

In addition to the use of conventional equipment in densification, manual operations, including hand-moulding and shaping are sometimes employed to make briquettes, such as charcoal dust mixed with binder [31], as well as low pressure densification machines.

In most cases, the composition of biomass and its morphological characteristics determine the level of pressure required in densification processes.

\subsubsection{Curing/Cooling}

The densified biomass leaving the densification unit is usually hot due to incidental or deliberate heating during densification, so a curing unit may be required to cool and dry it before packaging and storage. Densified biomass curing may take place at room temperature, or using equipment such as a box dryer and/or counter-flow cooler, which blows air through the fresh briquettes/pellets. Operational energy is required to supply air for drying or cooling, and curing at room temperature requires space with embodied energy [Muazu et al, manuscript in review].

\subsubsection{Screening}

The produced briquettes/pellets may be screened to remove fines and shattered briquettes/pellets before packaging or storage [12]. However, the specific impact of densified biomass screening is not available in the literature.

\subsubsection{Packaging}

Densified biomass may be packaged to make it easier to load, transport and distribute, as well as protecting it from weathering. Packaging is mostly important when the densified biomass is being distributed for domestic applications or small-scale thermal sites, whereas packaging is usually avoided for large-scale thermal conversion sites, which may use specialised transport. Packaging can be carried out manually or using equipment such as thermal shrink packaging [32]. The packaging unit can be considered as a moderate energy consumption unit relative to high energy units such as drying, and low energy units such as storage. 


\subsubsection{Feed biomass/densified biomass transportation}

The transportation requirement of loose biomass from source to densification site varies with the type of biomass residue to be densified, particularly its density, and the distance between the biomass production and densification sites [e.g., 12,13,14]. The associated environmental impacts also depend on the type of vehicle used in both cases. Transportation is excluded from the reference "gate-to-gate" system boundary, but in a typical "A-to-D" gate-to-gate LCA of biomass densification systems found in the literature, the transportation stage consumed up to $23 \%$ of the total energy of densified biomass production [e.g., 15] (Table 1). Nguyen et al [16] found that greenhouse gas ( $\mathrm{GHG}$ ) emissions associated with the biomass logistics in ethanol production chain, are most sensitive to the transportation of densified biomass with emissions of 0.2 to $13 \mathrm{CO}_{2}$-eq $\left(\mathrm{g} \mathrm{MJ}^{-1}\right)$. One of the possible ways to reduce the impact of transportation is densification of the loose biomass at source (onsite) [e.g., 17,18].

\section{Previous work on LCA of biomass densification systems}

Studies selected for this study were found by searching scientific and technical databases including, Web of Science, Science Direct, FAO, and Google Scholar. Combining keywords such as "biomass", densification", "briquetting" and "LCA", the authors found a total of 87 publications. 19 out of these studies reported environmental impacts specifically for biomass densification, while other studies embedded densification within the energy production system, which made it difficult to extract quantitative information specific to the densification unit from those studies.

The 19 LCA studies with accessible information about biomass densification are summarised in Table 2, including the types of biomass densified, the densification technologies, the system boundaries, and the environmental impacts. Environmental impacts are summarised as reported, and also normalised to uniform units, including a uniform functional unit (1 MJ densified biomass energy content) in the denominator, to enable comparison of the results from different studies.

Figure 2 and Figure 3 show the information in Table 2, after conversion to the reference densification plant entry gate-to- exit gate (B to $\mathrm{C}$ in Figure 1) system boundary, i.e., including all capital and operating components of the densification system, again with normalisation of the units. 
For the 19 reviewed studies, five different system boundaries were used, and none reported a complete "cradle-to-grave" LCA of the densification process (Figure 1). Three [13,17,26] already had the reference "B-to-C" gate-to-gate system boundary. Four other studies [12,33; 29,18] used a "gate-to-grid" system boundary. Eight studies [15,16,21,34,35,36,37,38] considered a "cradle-to-gate" system boundary. Njenga et al. [32], Kabir \& Kumar [39], Sultana \& Kumar [19], Fantozzi \& Buratti [20] considered a "cradle-to-grid" system boundary, whereby the definition of cradle, gate and grid varied for the different studies, as indicated in Table 2. These studies also used different functional units, for example, the functional unit was defined as the annual mass of fuel pellets by Bergman et al [34], whereas Chiew \& Shimada [17] defined the functional unit in terms of the mass of processed feed biomass residues.

The indicators used to assess the environmental impacts of the fuel densification varied across the studies, and included energy consumed in briquette production per unit of energy produced by the densified biomass, GHG emissions, as well as a variety of others. 
A detailed LCA of biomass densification, with reporting of a variety of impacts, was conducted in 13 of the reviewed studies [13,15,17,19,20,26,33,34,35,36,37,38,39] using impact assessment methodologies such as CML 2 baseline 2000, EDIP 2003, Eco-indicator 99, and Recipe methodologies. The remaining 6 studies used energy and greenhouse gas (GHG) emissions to assess the sustainability of the biomass densification systems.

As is the case with other LCA studies of bioenergy systems, variations can be observed among and within different scenarios of the reported outcomes of the LCAs (Table 2, Figure 2 and Figure 3). For all the reviewed studies, the life cycle energy consumption of the gate-to-gate densification systems ranged between 20 to $900 \mathrm{~kJ} \mathrm{MJ}^{-1}$. The lower the total energy consumption, the more sustainable the biofuel. For example, Kabir \& Kumar [39] showed that a densification energy of $290 \mathrm{~kJ} \mathrm{MJ}^{-1}$ and above is unsustainable.

The GHG emissions of the gate-to-gate densification systems from the reviewed studies ranged from 0.6 to $50 \mathrm{CO}_{2}$-eq $\left(\mathrm{g} \mathrm{MJ}^{-1}\right)$, of densified biomass energy content, while a range of 190 to $230 \mathrm{CO}_{2}$-eq $\left(\mathrm{g} \mathrm{MJ}^{-1}\right)$, of electricity generation with densified biomass was estimated on a cradle-to-grid basis. To give an indication of the sustainability of this range of GHG emission it can be compared, for example, to the total $\mathrm{CO}_{2}$ emissions of $230 \mathrm{CO}_{2}-\mathrm{eq}\left(\mathrm{g} \mathrm{MJ}^{-1}\right)$ from electricity generation with loose biomass (rice straw) [45], or $350 \mathrm{~g} \mathrm{CO}_{2}$-eq $\left(\mathrm{g} \mathrm{MJ}^{-1}\right)$ with coal, for a cradle-to-grid system boundary [45].

The most obvious impacts of densification are on energy consumption and GHG emissions associated with transportation, where we might roughly assume that any increase in bulk density is associated with proportional reductions in fuel use and transport emissions reduction. Given that the bulk density increase factors reported in 5 of the reviewed studies ranged from 2.3 to 5.5 [12,15,19,34,39], and assuming transport energy use of $2.5 \mathrm{MJ} \mathrm{t}^{-1} \mathrm{~km}^{-1}$ and transport emissions of $126 \mathrm{CO}_{2}$-eq $\left(\mathrm{g} \mathrm{t}^{-1} \mathrm{~km}^{-1}\right)$ [46], this suggests that densification reduces net energy consumption in these studies by 200 to $1000 \mathrm{~kJ} \mathrm{MJ}^{-1}$ and $\mathrm{GHG}$ emissions by 9 to $50 \mathrm{CO}_{2}$-eq (g $\mathrm{MJ}^{-1}$ ) for a hypothetical maximum transport distance of $500 \mathrm{~km}$ and target transport load of 20 $\mathrm{td}^{-1}$.

The compiled LCA outcomes varied over a wide range and normal probability plots (not shown) of the LCA outcomes in Figure 2 and Figure 3 suggest that the variations are not attributable to random error, which further indicates the significant effects of the various methodological choices employed on the LCA outcome. More extreme outlier values were also observed, e.g., outlier values of $0,0.01$, and 700 were excluded from the summary of GHG 
emissions in Figure 3. The studies by Njenga et al [31] and Rousset et al [21] were not included in the plot but are further discussed below. The reliability of the outlier case reported by Fantozzi \& Buratti [20] was very low due to high weight allocated to equipment during characterisation and weighting phases of the LCA, and was thus excluded from the analysis.

Wide variations in LCA outcomes are also common in the literature. Most existing LCA studies of bioenergy (and other) systems have different specific goals and have therefore adopted different approaches, leading to different results. Even for studies with similar goals and input and output flows, variations in LCA outcomes may be observed, e.g., with a range of 4.4 to $100 \mathrm{CO}_{2}$-eq $\left(\mathrm{g} \mathrm{MJ}^{-1}\right) \mathrm{J}^{-1}$ in a review of hundreds of LCA studies on biopower technologies carried out between 1980 to 2010 [47], $-1.3 \times 10^{3}$ to $80 \mathrm{CO}_{2}$-eq $\left(\mathrm{g} \mathrm{km}^{-1}\right)$ travelled in a review of 53 LCA studies using ethanol E100 [7], and 0.3 to $193 \mathrm{CO}_{2}$-eq $\left(\mathrm{g} \mathrm{MJ}^{-1}\right)$ electricity, and 1.6 to $21 \mathrm{CO}_{2}$-eq $\left(\mathrm{g} \mathrm{MJ}^{-1}\right)$ in a review of $58 \mathrm{LCA}$ studies of various biomass fuels [11]. For the latter review, outlier $\mathrm{GHG}$ emission values widened the range to -113 to $301 \mathrm{CO}_{2}$-eq $\left(\mathrm{g} \mathrm{MJ}^{-1}\right)$ electricity and 1.6 to $67 \mathrm{CO}_{2}$-eq $\left(\mathrm{g} \mathrm{MJ}^{-1}\right)$ heat generated. Such wide variations have been attributed to factors such as: data source [7], data age [48], methodological issues including definition of the functional unit and system boundary [49], and allocation procedures [50,51]. For example, in the present review, the reporting of results on the basis of biomass energy content implies that the variations in heating values of different types of densified biomass (15 to $26 \mathrm{MJ} \mathrm{kg}^{-1}$ ) among the reviewed studies influence the LCA results. The GHG emissions and overall LCA results can be sensitive to the scale of production [e.g., 16,29], but a clear correlation between scale of production and life cycle energy or GHG emissions was not observed for the reviewed studies.

The common sources of variation between the LCAs are discussed further in the following sections. However, it should be noted that the literature sources do not report all of the details of their analyses, which makes the cause of the very wide variation in results from different studies difficult to determine.

\section{Sources of uncertainty in LCA of biomass densification systems}

\subsection{System boundary}

Definition of different system boundaries is a significant source of variation in LCA results among the reviewed studies. For example, a study by Rousset et al [21] showed that for each 
$\mathrm{kg}$ of briquettes produced from wood charcoal fines and starch, an estimated $100 \mathrm{~g}$ of CO 2 -eq was sequestered per MJ of briquette energy content in a cradle-to-gate system boundary, while emission of $700 \mathrm{CO}_{2}$-eq $\left(\mathrm{g} \mathrm{MJ}^{-1}\right)$ was associated with the gate-to-gate system boundary. The inclusion of the agricultural stage in the cradle-to-gate system boundary, reduced the net GHG emission of the densification system. However, it seems more appropriate to use $\mathrm{CO}_{2}$ capture in the agricultural stage to offset the dependent $\mathrm{CO}_{2}$ emissions in biomass conversion, rather than to include them in the biomass densification subsystem, which is independent of the agricultural stage.

This source of variation was eliminated by separating out the components of the reference "gate-to-gate" boundary system for each of the literature sources in Figure 2 and Figure 3. However, significant variations can still be observed between some of the studies, especially for the GHG emissions. For example, a study by Reed et al, [37] showed that a gate-to-gate LCA of wood residue pelleting emitted $10 \mathrm{CO}_{2}$-eq $\left(\mathrm{g} \mathrm{MJ}^{-1}\right)$, while, for the same gate-to-gate system boundary, 2 and $7 \mathrm{CO}_{2}$-eq (g) were associated with corn stalk briquetting by $\mathrm{Hu}$ et al, [12] and EFB briquetting by Chiew \& Shimada [17] respectively. Hu et al [12] used an integrated briquetting system and did not include the burden of conveying and packaging unit. The conveying and packaging units can respectively contribute up to $22 \%$ and $7 \%$ of the total life cycle GHG emissions of the gate-to-gate densification system (Table 1). Likewise, the EFB briquetting had only four production stages including conveying, size reduction, drying and briquetting (pressing of the EFB into cylindrical moulds) [17], whereas pelleting of the wood residue by Reed et al, [37] included all the other units of the densification system (including conveying, size reduction, drying and densification) and additional energy used for pellet lubrication.

This indicates that even for the same nominal system boundary, the LCA outcome is highly dependent on the specific components and activities included in the system.

\subsection{Densification variables}

The type of densification technology employed in the production of briquettes or pellets can influence the properties of densified fuels [e.g., 1,23] as well as the results of an LCA. For example, the use of manual operations in briquetting of charcoal dust resulted in total GHG emissions of $0 \mathrm{CO}_{2}$-eq $\left(\mathrm{g} \mathrm{MJ}^{-1}\right)$ of briquette energy content [31], while use of conventional densification equipment (e.g., briquette press and pellet mill) resulted in GHG emissions of 0.6 
to $50 \mathrm{CO}_{2}$-eq $\left(\mathrm{g} \mathrm{MJ}^{-1}\right)$ briquette energy from charcoal fines. The manual collection of binding agent as spoil gathered from pit digging by roadsides and riversides, and the transportation of these materials by foot from sources to the briquetting point, and the use of water from natural shallow wells, in the study by Njenga et al, [31], avoided the net energy input into the system that would be required by electrical machinery. However, other work has shown that the durability and energy density of manually densified biomass may be less than that of densified biomass produced using high pressure compaction equipment [e.g.,22]. Therefore, a balance between lower environmental impacts and quality of densified biomass should be considered. It is also important to look into the social impact of employing manual operations in biomass densification.

The high outlier values for GHG emissions were associated with charcoal briquetting. Charcoal biomass has poor plasticity and normally requires high energy for densification using conventional equipment, as well as the need for a binder, which further increases the storage space requirement for raw binder (Table 1) and energy requirement of curing the densified biomass. However, the charcoal dust used by Njenga et al [31] and charcoal fines used by Rousset et al [21] had different characteristics (e.g., particles size and source of charcoal), which also influence the densification processes and LCA results.

In another example, the life cycle energy of densification with a pellet mill by Kabir \& Kumar [39] was 22 times higher than the life cycle energy of densification with an integrated flat die briquette machine by Hu et al [12].

In addition to the densification technology, the biomass material properties such as moisture, particle size, species and density, affect the energy requirement of the densification system [e.g., 19]. From Figure 2, densification of biomass from whole trees had the highest life cycle energy consumption, while agricultural residues such as wheat straw had lower life cycle energy consumptions. This can be attributed to less energy required for drying and size reduction of wheat straw compared with wood biomass, as these two units contribute significantly to the total densification life cycle energy and GHG emissions (Table 1).

\subsection{Functional unit}

The functional unit is critical in LCA as it forms the basis for comparison between different systems [e.g., 7,11]. 
The functional unit definition was inconsistent among the reviewed studies, which makes it difficult to compare and evaluate results between these studies. The functional unit may be defined in terms of system input (e.g., mass of biomass residues), output (mass of densified biomass, or unit of energy delivered), or annual production or unit land area. The great majority of biomass densification LCAs used an output-related functional unit [e.g., 31,39]. Cherubini \& Stromman [8] also reported that $73 \%$ of 90 LCAs of different bioenergy technologies defined an output-related functional unit. Normalising the functional unit of the LCA studies to a uniform unit of $1 \mathrm{MJ}$ densified biomass energy (Table 2, Figure 2 and Figure 3) eliminated this source of variation.

\subsection{Data source and age}

LCA requires data on material and energy flows, and processes/infrastructure such as equipment and buildings. The quality of data used in the LCA strongly affects the reliability of the LCA results.

Availability of full-scale data for LCA of biomass densification systems is limited, as highlighted by Fantozzi \& Buratti [20]. This can be attributed to the fact that biomass densification is still gaining popularity in the bioenergy system, and some of the equipment currently in the market is either made locally from local materials, or by a few established manufacturers who do not report detailed information. This often results in the use of numerous assumptions and/or use of mixed data in LCA studies [e.g.,15,40], which limits the reliability of the outcome [20] and increases variations among existing studies [e.g.,52].

The results of an LCA based on data from the literature can be expected to be different from LCA results based on data collected directly from an existing briquetting plant. For example, for the reference gate-to-gate system, the GHG emissions of $1.3 \mathrm{CO}_{2}$-eq $\left(\mathrm{g} \mathrm{t}^{-1}\right)$ determined by Tabata et al. [29; 15 in Figure 2] based on literature data differed from the $4.8 \mathrm{~g} \mathrm{CO}_{2}$-eq $\left(\mathrm{g} \mathrm{t}^{-}\right.$ ${ }^{1}$ ) determined by Hu et al, [12; 5 in Figure 2] with real data for an existing plant; both differed substantially from the $46 \mathrm{CO}_{2}$-eq $\left(\mathrm{g} \mathrm{t}^{-1}\right)$ determined by Waewsak et al [33; 9 in Figure 2] which had a mixture of data sources (i.e., reports and an existing plant). On the other hand, Fantozzi \& Buratti [20] reported a relatively minor difference (a factor of 1.3) between LCA results based on an existing plant as compared with literature data. Some of the studies provided limited information on the data and sources used in the LCA studies, and it is difficult to be certain of the reasons for the very wide variation in results. 


\subsection{Allocation}

In LCA, the environmental impacts may be allocated to different products in a system based on their share of mass, energy, economic market price; in some cases, allocation is avoided [53], for example, through system expansion [4]. According to Ekvall \& Finnveden [53], a methodological allocation problem arises when a multifunctional process fulfils one or more functions for the product life cycle that is investigated, and a different function, or set of functions for other products.

The effect of allocation and expansion methodologies on LCA results of bioenergy systems (e.g., heat, electricity and liquid fuels) has been discussed by a number of authors [e.g., 8,54] indicating the strong need for standard allocation procedures between different products in multifunctional bioenergy systems. However, only a few authors [e.g., 11] have developed and suggested a robust approach for dealing with allocation in LCAs. Some recognised standards including EU [55] and PAS 2050 [55] also recommend specific procedures for handling allocation problems in LCA.

Unlike other bioenergy systems, or a cradle-to-grave LCA of biomass densification, gate-togate biomass densification is associated with a single product (the fuel briquette/pellet), which implies that all energy use and emissions are allocated to the product "densified biomass". The need for allocation is avoided as it arises only in the case of a multi- input densification process [e.g., 21,33].

For the pre-gate activities, some of the reviewed studies used economic market price, and energy to allocate environmental burden to co-products [e.g., 12,17], while some studies used allocation on a mass basis [e.g.,19,36] and some did not clearly indicate the allocation approach used in the study [e.g.,29]. The impact of allocation methodology on LCA results was demonstrated by Reed et al, [37], where the environmental impact of wood residue production reduced by $97.5 \%$ when economic rather than mass allocation was employed between the wood residue and a wood flooring product. Some key points on the principles of different allocation methodologies, their applications and limitations, were reported by Borrion et al [7].

\section{Uncertainty analysis in LCA of biomass densification systems}

Nearly all LCA studies are associated with uncertainties which can result in over- or underestimation of the environmental impacts [57], thereby affecting the quality and usefulness of 
the LCA outcome. Uncertainty analysis aims to provide additional information for decisionmaking on the basis of a presented LCA outcome. Some LCA studies [e.g.,58,59] include a quantitative analysis of uncertainty, which is usually expressed as a probability distribution of the resulting outcome, while other studies adopt a qualitative approach to express uncertainties [60].

In treating uncertainties in LCA, appropriate classification of the various sources of uncertainties is useful. Different typologies have been used to classify uncertainty in LCA, for example; Lloyd \& Ries [58] and Huijbregts et al, [61] described uncertainty in input data as "parameter uncertainty", in normative choices as "scenario uncertainty" and uncertainty associated with mathematical relationships as "model uncertainty". In many biomass densification LCAs, uncertainty mainly comes from the input parameters (inaccurate data, lack of knowledge), and sometimes from various assumptions and simplifications of the densification system structure (2.2.4 and 4.4), also referred to as methodological choices /case scenarios. Loucks [62] classified uncertainty into "knowledge uncertainty", "decision uncertainty" and "natural variability". Arguably the latter includes "Temporal variability" and "Spatial variability" [59].

Classification and ranking of the possible sources of uncertainties in LCA of biomass densification would provide better understanding for future LCAs, as well as information for interpretation of LCA results in decision-making.

Therefore, the possible sources of uncertainty within the reference gate-to-gate biomass densification LCA (including transportation) have been summarised and classified into parameter, methodological and embodied impact uncertainties in Figure 4 and Figure 5, where:

- Parameter uncertainty (as also defined by Huijbregts [61]) in biomass densification LCA can arise from errors in densification process inputs, various characteristics of densification technologies, and their specific emission factors, such as discussed above in 4.2 and 4.4. It includes knowledge uncertainty and natural variability (as defined by Loucks [62]).

- Methodological uncertainty concerns the procedures and assumptions employed to assess the densification process, including scenario and modelling uncertainties [61], and decision uncertainty [62], e.g., data collection procedures and the aspects discussed above in 4.1, 4.3 and 4.5. 
- Embodied impact uncertainty is associated with embodied environmental impacts in the biomass densification system, such as steel production and electricity generation.

The listed sources of uncertainty were qualitatively categorized as high, medium or low depending on effect of the uncertainty source on reliability of the LCA outcome. These categories of uncertainty were also reported by Salway \& Shaddick [57], which also describes these categories as context specific, i.e., the categorization might be different for processes other than biomass densification.

Figure 4 and Figure 5 showed that limited, highly variable and inconsistent data results in more high parametric and methodological uncertainties, compared with the embodied impact uncertainty. These are further described in the following section.

Parameter uncertainty is often ignored in LCA of biomass densification. Some studies did include an analysis of the sensitivity of LCA outcomes to variations in selected LCA parameters, though without further analysis of uncertainty in the LCA studies [e.g., 15,39]. In dealing with uncertainty in process inputs, Adams et al, [15] accounted for variance associated with the energy required for biomass drying, by using low, medium and high values to evaluate the sensitivity of the LCA outcomes to possible changes in the drying energy. Kabir and Kumar [39] explored 4 case scenarios to evaluate the sensitivity of the LCA outcomes to possible changes in LCA components including farming operations (case 1), silviculture and road construction (case 2), impact of grid emissions (case 3), and variable transportation distance (case 4). Nguyen et al [16] also reported uncertainties in advanced biomass feedstock logistics supply chains. However, more than $80 \%$ of the reviewed studies did not provide information about uncertainties in the LCA parameters, which suggests a limited appreciation of their effects on the reliability of the LCA outcome.

Methodological choices employed in LCA studies are also associated with uncertainties, which can be associated with insufficient standard methods [e.g., 8] (4.5). This often results in different assumptions in different LCA studies, which increases the uncertainty in the LCA outcome. For example, data collection methods and impact allocation procedures in transportation of biomass/briquettes are inconsistent between some LCA studies of biomass densification [e.g., 13,36]. 
In the case of embodied impact uncertainty, standard databases, such as ecoinvent, provide embodied impact data for most product life cycle components such as materials, energy, and transport, which has reduced the level of uncertainty arising from this source. As such, the embodied impact sources of uncertainty had only a medium potential effect on the reliability of the LCA outcome (Figure 4 and Figure 5).

An understanding of the relationship between research objectives and selected LCA parameters, is expected to improve understanding of the possible sources of uncertainty in the LCA studies of biomass densification system. For example, Rousset et al [21] assessed the environmental impacts of an existing briquette production system, a large part of the data required were mainly collected from the existing densification plant. In this case, uncertainty may arise from the mode in which these data were obtained, the age of the plant, and the nature of operations. Adams et al [15] assessed the impacts of integrating a torrefaction process in wood pellet production, by comparing two different scenarios, using simulated pellet production system. Data required for the assessment were mainly collected from literature, while series of assumptions were also employed. In this case, uncertainty may arise from the various assumptions used in the study, variations in properties of the pelleting feeds, and variations in the quality of data collected for the different scenarios. For all the reviewed studies, parameters selected were highly dependent on the objectives, indicating a close relationship between objective of LCA study and selected LCA parameters. However, even studies with similar objectives employed different parameters, this can be attributed to other specific goals and assumptions employed in the LCA (section 3).

\section{Conclusions and Recommendations}

This study has reviewed previous work on LCA of biomass densification into briquettes and pellets. It has assessed the current status and identified gaps in understanding in the LCA of biomass densification.

The existing studies on LCA of biomass densification provide insufficient and inconsistent information, due to different choices in system boundary, functional unit, allocation procedure, densification technology and biomass residues. Most of the reviewed studies attributed most of the energy use and greenhouse gas (GHG) emissions to transportation, drying, size reduction and densification. The energy and GHG emissions of the gate-to-gate densification system 
were highly sensitive to the technology and feed material used in densification, and scale of production.

One of the reviewed studies reported zero energy and GHG emissions as a result of the use of manual operations, and there were three other outliers. The remaining studies had normalised values of energy and GHG emissions in the range of 20 to $900 \mathrm{~kJ} \mathrm{MJ}^{-1}$, and 0.6 to $50 \mathrm{CO}_{2}$-eq $\left(\mathrm{g} \mathrm{MJ}^{-1}\right)$ densified biomass energy content respectively. Assuming that the biggest impact of densification is on transport fuel use, densification could reduce net energy consumption by 200 to $1000 \mathrm{~kJ} \mathrm{MJ}^{-1}$, and GHG emissions by 9 to $50 \mathrm{CO}_{2}$-eq $\left(\mathrm{g} \mathrm{MJ}^{-1}\right)$. On this basis, it can be concluded that biomass densification is a worthwhile addition to the biomass energy conversion system.

A qualitative uncertainty analysis showed that parametric and methodological uncertainty sources in biomass densification can substantially reduce the reliability of the LCA outcome (Figure 4 and Figure 5).

The following recommendations can be adopted in future LCA studies of biomass densification, to improve consistency and reliability of LCA studies.

Studies should expand their analysis to cover a detailed and wider range of potential environmental impacts of biomass densification, as only few of the studies reported detailed environmental impacts [e.g., 15,33]

Since biomass properties are highly variable, and contributes to the variation in LCA outcomes of biomass densification systems (e.g., Rousset et al [21] and Njenga et al [31]), an understanding of how these properties affect the environmental impacts of biomass densification systems needs to be developed.

> Studies would benefit from a database specific to biomass densification systems, to provide more flexibility during LCA and reduce inconsistency in LCA studies as well as uncertainty in the LCA outcome, as only 2 [34,37] out of the 19 reviewed studies focused on inventory development for pelleting of switchgrass and wood biomass, respectively.

$>$ LCA results should be reported with the associated uncertainties to improve clarity and usefulness of the resulting outcomes, as most of the reviewed studies did not report uncertainty associated with the LCA outcomes. 


\section{Acknowledgement}

The authors are grateful to the Nigerian Petroleum Development Fund (PTDF) for funding this research.

\section{References}

[1] J.S. Tumuluru, C.T. Wright, K.L. Kenney, J.R. Hess, A review of biomass densification systems to develop uniform feedstock commodities for bioenergy application, Idaho National Laboratory, Idaho Falls, ID, USA. J Biofuels, Bioproducts and Biorefining. 5 (2011) 683-707.

[2] A. Uslu, A.P.C. Faaij, P.C.A. Bergman, Pre-treatment technologies, and their effect on international bioenergy supply chain logistics. Techno-economic evaluation of torrefaction, fast pyrolysis and pelletisation. Energy. 33 (2008)1206-1223.

[3] A.C. Caputo, M. Palumbo, P.M. Pelagagge, F. Scacchia, Economics of biomass energy utilization in combustion and gasification plants: Effects of logistic variables. J Biomass and Energy. 28 (2005) 35- 51.

[4] ISO 14044. The International Organisation for Standardization. (2006), Environmental Management-Life Cycle Assessment-Principles and framework, Available at https://www.iso.org/obp/ui/\#iso:std:iso:14044:ed-1:v1:en accessed on 15/03/14 1:44.

[5] G. Finnveden, Methodological aspects of life cycle assessment of integrated solid waste management systems. J Resources, Conservation and Recycling. 26 (1999) 173-87.

[6] IEA, International Energy Agency. (2011), Using a Life Cycle Assessment Approach to Estimate the Net Greenhouse Gas Emissions of Bioenergy: A strategic report prepared by; Neil Bird, Annette Cowie, Francesco Cherubini, Gerfried Jungmeier. Available at http://www.ieabioenergy.com/wp-content/uploads/2013/10/Using-a-LCA-approach-toestimate-the-net-GHG-emissions-of-bioenergy.pdf last accessed on 13/10/2017 4:49.

[7] A.L. Borrion, M.C. McManus, G.P. Hammond, Environmental life cycle assessment of lignocellulosic conversion to ethanol: A review. J of Renewable and Sustainable Energy Reviews. 16 (2012) 4638-4650.

[8] F. Cherubini, A.H. Stromman, Life cycle assessment of bioenergy systems: State of the art and future challenges. J Bioresource Technology. 102 (2011) 437-4351. 
[9] L. Coniglio, J.A.P. Coutinho, J.Y. Clavier, F. Jolibert, J. Jose, I. Mokbel, D. Pillot, P. Noelle, M. Sergent, V. Tschamber, Biodiesel via supercritical ethanolysis within a global analysis "feedstocks-conversion-engine" for a sustainable fuel alternative. J. Progress in Energy and Combustion Science. 43 (2014) 1-35.

[10] A.T. Fruergaard, T. Davide, T. Roberto, B. Alessio, Life cycle assessment of thermal Waste-to-Energy technologies: Review and recommendations. Waste Management. 37 (2014) 104-115.

[11] S. Muench, E. Guenther, A systematic review of bioenergy life cycle assessments. Applied Energy. 112 (2013) 257-273.

[12] J. Hu, T. Lei, Z. Wang, X. Yan, X. Shi, Z. Li, X. He, Q. Zhang, Economic, environmental and social assessment of briquette fuel from agricultural residues in China e A study on flat die briquetting using corn stalk. J of Energy. 64 (2014) 557-566.

[13] A. Kylili, E. Christoforou, P.A. Folakaides, Environmental evaluation of biomass pelleting using life cycle assessment. J. Biomass and Bioenergy. 84 (2016) 101-17.

[14] C. Feng, X. Yu, H. Tan, T. Liu, T. Hua, Z. Zhang, S. Qiu, L. Chen, The economic feasibility of a crop-residue densification plant: A case study for the city of Jinzhou in China. J Renewable and Sustainable Energy Reviews. 24 (2013) 172-80.

[15] P.W.R. Adams, J.E.J. Shirley, M.C. McManus, Comparative cradle-to-gate life cycle assessment of wood pellet production with torrefaction. J. Applied Energy. 138 (2015) 367-80.

[16] L. Nguyen, K.G. Cafferty, E.M. Searcy, S. Spatari, Uncertainties in life cycle greenhouse emissions from advanced biomass feedstock logistics supply chains in Kansas. J. Energies. 11 (2014) 7125-46.

[17] Y.L. Chiew, S. Shimada, Current state and environmental impact assessment for utilizing oil palm empty fruit bunches for fuel, fibre and fertilizer: A case study of Malaysia. J Biomass and Bioenergy. 51 (2013) $109-24$.

[18] J.L. Shie, C.Y. Chang, C.S. Chen, D.G. Shaw, Y.H. Chen, W.H. Kuan, H.K. Maf, Energy life cycle assessment of rice straw bio-energy derived from potential gasification technologies, $\mathrm{J}$ of Bioresource Technology.102 (2011) 6735-41. 
[19] A. Sultana, A. Kumar, Development of energy and emission parameters for densified form of lignocellulosic biomass. J. Energy. 36 (2011) 2716-32.

[20] F. Fantozzi, C. Buratti, Life cycle assessment of biomass chains: wood pellet from short rotation coppice using data measured on a real plant. J. Biomass and Bioenergy. 34 (2010) 1796-1804.

[21] P. Rousset, A.C. Pires, A. Sablowski, T. Rodrigues, LCA of eucalyptus wood charcoal briquettes. J of cleaner production. 19 (2011) 1647-53.

[22] R.I. Muazu, J.A. Stegemann, Effects of operating variables on durability of fuel briquettes from rice husks and corn cobs. J Fuel Processing Technology. 133 (2015)137-145.

[23] P.D. Grover, S.K. Mishra, Biomass Briquetting: Technology and Practice, Food and Agricultural Organisation of the United States, Bangkok Thailand. (1996) 1-10.

[24] W.A. Amos, Report on biomass drying technology, National Renewable Energy Laboratory (NREL) 1998. Available at https://www.osti.gov/scitech/biblio/9548 last accessed on $13 / 10 / 20174: 56$.

[25] M. Stahl, K. Granstrom, J. Berghel, R. Renstrom, Industrial processes for biomass drying and their effects on the quality properties of wood pellets, Biomass and Bioenergy. 27 (2004) $621-8$.

[26] S. Mani, S. Sokhansanj, X. Bi, A. Turhollow, Economics of producing fuel pellets from biomass, American Society of Agricultural and Biological Engineers. 22 (2006) 421-6.

[27] N. Kaliyan, R.V. Morey, Tiffany DG, Lee WF. Life cycle assessment of a corn stover torrefaction plant integrated with a corn ethanol plant and a coal fired power plant. J of biomass and bioenergy. 63 (2014) 92-100.

[28] N. Kaliyan, R.V. Morey, Factors affecting strength and durability of densified biomass products, Biomass Bioenergy. 33 (2009) 337-359.

[29] T. Tabata, H. Torikai, M. Tsurumaki, Y. Genchi, K. Ukegawa, Life cycle assessment for co-firing semi-carbonised fuel manufactured using woody biomass with coal: A case study in the central area of Wakayama, Japan. J Renewable and Sustainable Energy Reviews.15 (2011) 2772-2778. 
[30] P.T.M. Thao, K.H. Kurisu, K. Hanaki, Evaluation of strategies for utilizing rice husk based on life cycle cost analysis in relation to greenhouse gas emissions in An Giang province, Vietnam. J Biomass and Bioenergy. 37 (2011)122-131.

[31] M. Njenga, N. Karanja, H. Karlsson, R. Jamnadass, M. Iiyama, J. Kithinji, C. Sundberg, Additional cooking fuel supply and reduced global warming potential from recycling charcoal dust into charcoal briquette in Kenya, journal of Cleaner Production 81 (2014) 81-88.

[32] AGICO GROUP (2014), Anyang General International Co., Ltd. Biomass briquetting plant, available at http://www.biomass-briquette.com/Product-List-of-AGICO-BiomassBriquetting-Equipment.pdf last accessed 23/06/2014.

[33] J. Waewsak, P. Nutongkaew, C. Kongruang, S. Tirawanichakul, Environmental Life Cycle Assessment of Small Scale Mixed Rice Husk-Glycerol Briquettes Gasification Power Plant. International Conference on Alternative Energy in Developing Countries and Emerging Economies, Energy Procedia, 79 (2013) 1-1060.

[34] R.P. Bergman, D.L. Reed, A.M. Taylor, D.P. Harper, D.G. Hodges, Cradle-to-gate life cycle assessment of switchgrass fuel pellets manufactured in the South-eastern United States. Wood and Fibre Science. 47 (2015) 147-159.

[35] G.A. Tsalidis, Y. Joshi, G. Korevaar, W. de Jong, Life cycle assessment of direct co-firing of torrefied and/or pelletised woody biomass with coal in The Netherlands. J. Cleaner production. 81 (2014) 168-177.

[36] X. Li, E. Mupondwa, S. Panigrahi, L. Tabil, P. Adapa, Life cycle assessment of densified wheat straw pellets in the Canadian prairies. Intl. J. Life Cycle Assess. 17 (2012) 420-431.

[37] D. Reed, R. Bergman, J.W. Kim, A. Taylor, D. Harper, D. Jones, C. Knowles, M.E. Puettmann, Cradle-to-Gate Life cycle inventory and impact assessment of wood fuel pellet manufacturing from hard wood flooring residue in the Southern United States. J. Forest products. 62 (2012) 280-288.

[38] F. Magelli, K. Boucher, H.T. Bi, S. Melin, A. Banoli, An environmental impact assessment of exported wood pellet from Canada to Europe. J. Biomass and Bioenergy. 33(2009) 434-441.

[39] M.R. Kabir, A. Kumar, Comparison of the energy and environmental performances of nine biomass/coal co-firing pathways. Bioresource Technology. 124 (2012) 394-405. 
[40] S. Mani, S. Sokhansanj, X. Bi, A. Kumar, A streamlined life cycle analysis of biomass densification process. In AlChE 2005 Annual Meeting, Cincinnati.

[41] ECN Phyllis2, database for biomass and waste, https://www.ecn.n1/phyllis2 Energy research Centre of the Netherlands.

[42] F. Miccio, G. Ruoppolo, G. Russo, M. Urciuolo, A. De Riccardis, Fluidized Bed Combustion of Wet Biomass Fuel (Olive Husks). J. Chemical Engineering Transactions. 37 (2014)1-6.

[43] B.M. Jenkins, L.L. Baxter, T.R. Miles Jr, T.R. Miles, Combustion properties of biomass. J. Fuel Processing Technology. 54 (1998) 7-46.

[44] B. Jenkins, Properties of Biomass, Appendix to Biomass Energy Fundamentals, EPRI Report TR-102107, January, 1993.

[45] S.M. Shafie, H.H. Masjuki, T.M.I. Mahlia, Life cycle assessment of rice straw-based power generation in Malaysia, Energy. 70 (2014) 401- 410.

[46] B.P. Weidema, Ch. Bauer, R. Hischier, Ch. Mutel, T. Nemecek, J. Reinhard, C.O. Vadenbo, G. Wernet, The ecoinvent database: Overview and methodology, Data quality guideline for the ecoinvent database version 3 (2013), www.ecoinvent.org

[47] H. Chum, A. Faaij, J. Moreira, G. Berndes, P. Dhamija, H. Dong, B. Gabrielle, A. Goss Eng, W. Lucht, M. Mapako, O. Masera Cerutti, T. McIntyre, T. Minowa, K. Pingoud, Life cycle greenhouse gas emissions for biopower technologies per unit of electricity generation, including supply chain emissions, Bioenergy 2011; In IPCC Special Report on Renewable Energy Sources and Climate Change Mitigation [O. Edenhofer, R. PichsMadruga, Y. Sokona, K. Seyboth, P. Matschoss, S. Kadner, T. Zwickel, P. Eickemeier, G. Hansen, S. Schlömer, C. von Stechow, (eds)], Cambridge University Press. Figure 2.11

[48] E. Audsley, K.F. Stacey, D.J. Parsons, G. Adrian, A.G. Williams, Estimation of the greenhouse gas emissions from agricultural pesticide manufacture and use. Report for Crop Protection association (2009). Available at:

https://dspace.lib.cranfield.ac.uk/bitstream/1826/3913/1/Estimation_of_the_greenhouse_gas emissions_from_agricultural_pesticide_manufacture_and_use-2009.pdf last accessed on 08/01/2016;1.05 am 
[49] S. Suh, M. Lenzen, G.J. Treloar, H. Hondo, A. Horvath, G. Huppes, O. Jolliet, U. Klann, W. Krewitt, Y. Moriguchi, J. Munksgaard, G. Norris, System boundary selection in life-cycle inventories using hybrid approaches. J of Environmental Science \& Technology. 3 (2004) 657664.

[50] A. Quek, R. Balasubramanian, Life cycle of energy and energy carriers from waste matterA review. J of Cleaner Production 2014; 79:18-31.

[51] E.I. Wiloso, R. Heijungs, C.R. Snoo, LCA of second generation bioethanol: A review of some issues to be resolved for good LCA practice. J of Renewable and Sustainable Energy Reviews. 16 (2012) 5295-5309.

[52] D.R. Johnson, H.H. Willis, A.E. Curtright, C. Samaras, T. Skone, Incorporating uncertainty analysis into life cycle estimates of greenhouse gas emissions from biomass production. Biomass and Bioenergy. 35 (2011) 2619-26.

[53] T. Ekvall, G. Finnveden, Allocation in ISO 14041 - a critical review. Journal of cleaner production. 9 (2001) 197-208.

[54] M.C. Heller, G.A. Keoleian, M.K. Mann, T.A. Volk, Life cycle energy and environmental benefits of generating electricity from willow biomass. Renewable Energy. 29 (2004)10231042.

[55] EU, (2009), Directives on the promotion of the use of energy from renewable sources, European Parliament, Directive 2009/28/EC, 23rd April 2009.

[56] PAS 2050 (2008), How to assess the carbon footprint of goods and services, Crown and Carbon Trust, London. UK. SimaPro Database Manual Methods Library 2002-2015.

[57] R. Salway, G. Shaddick, (2011), Implementation of Qualitative Uncertainty Guidance: Worked Example, Available at:

http://en.opasnet.org/en-opwiki/images/3/36/Example_qualitative_ uncertainty_analysis.pdf last accessed on, 04/11/14, 15:25.

[58] S.M. Lloyd, R. Ries, Characterizing, propagating and analysing uncertainty in life-cycle assessment: A survey of quantitative approaches. J. Industrial Ecology. 11 (2007) 161-179. 
[59] M.A.J. Huijbregts, LCA Methodology, Application of Uncertainty and Variability in LCA, Part I: A General Framework for the Analysis of Uncertainty and Variability in Life Cycle Assessment, Int. J. LCA. 5 (1998) 237-280.

[60] C.F. Chen, H.W. Ma, K.H. Reckhow, Assessment of water quality management with a systematic qualitative uncertainty analysis. J of Science of the Total Environment. 374 (2007) $13-25$.

[61] M.A.J. Huijbregts, W. Gilijamse, A.M.J. Ragas, L. Reinjnder, Evaluating uncertainty in environmental life cycle assessment. A case study comparing two insulation options for a Dutch one-family dwelling. J. Environmental Science and Technology. 37 (2003) 2600-2608.

[62] D.P. Loucks, E. van Beek, J.R. Stedinger, J.P.M. Dijkman, Water resources systems planning and management: an introduction to methods, models and applications. Paris: UNESCO, 2005, chapter 9, 255-261.

[67] M. Goedkoop, M. Olele, J. Leijting, T. Ponsioen, E. Meijer, Simapro software, Simapro 6-Introduction to LCA with Simapro (2013), Amersfoort the Netherlands: PRé consultants, (www.pre-sustainability.com). 
Figure 1: Cradle-to-grave life cycle stages of biomass densification, including biomass production and conversion to energy (red solid line indicates the system boundary for the reference gate-to-gate LCA discussed in the text and used in normalisation of reviewed studies)

Figure 2: Comparison of literature values (see column 1 of Table 1 for codes) of life cycle energy consumption per MJ for a reference gate-to-gate biomass densification system

Figure 3: Comparison of literature values (see column 1 of Table 1 for codes) of life cycle GHG emissions in $\mathrm{CO}_{2}$-eq (g MJ'-1) for a reference gate-to-gate biomass densification system

Figure 4: Possible sources of uncertainty in fuel densification LCA (Pre-densification)

Figure 5: Possible sources of uncertainty in fuel densification LCA (Post-densification) 


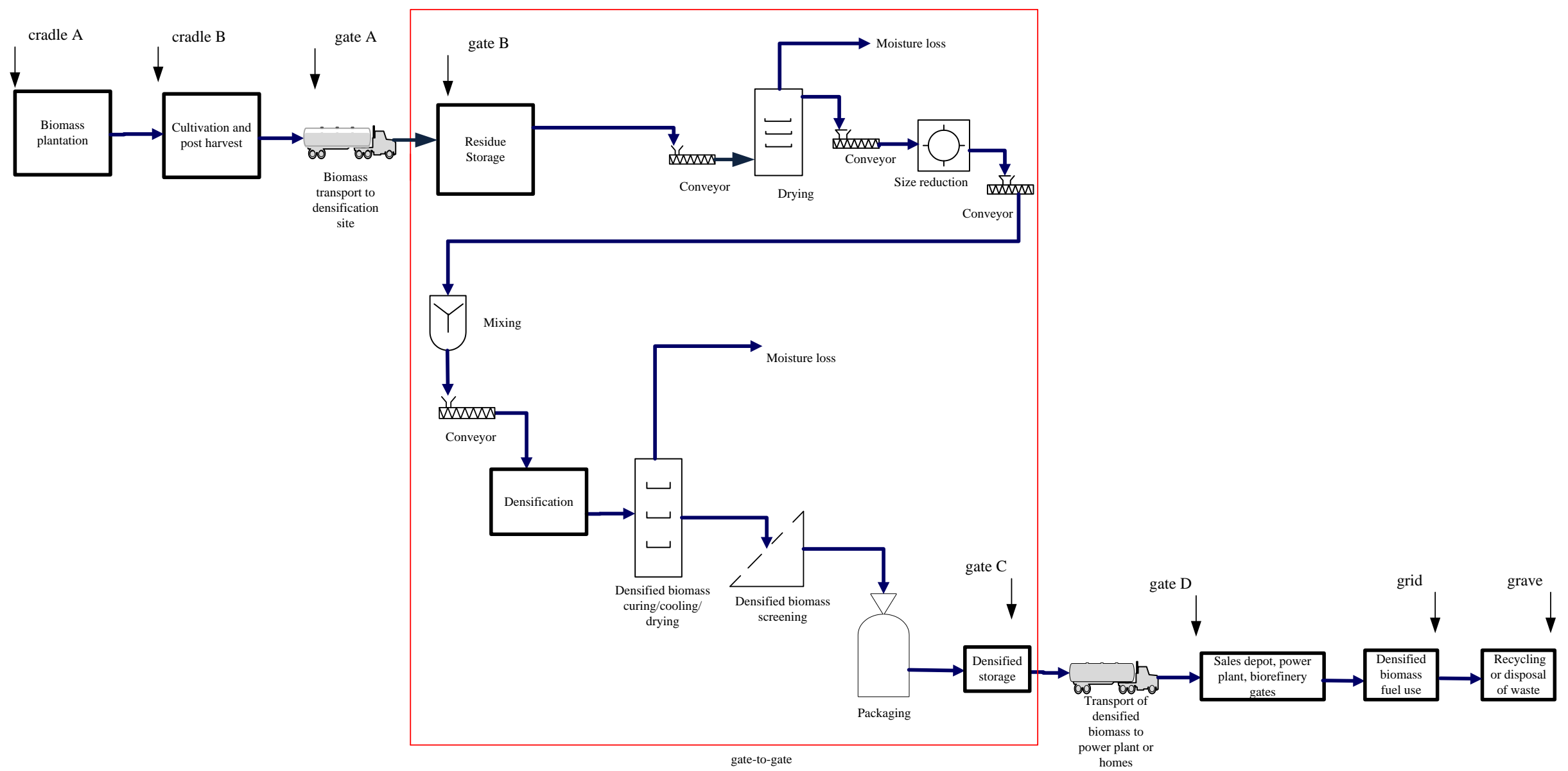




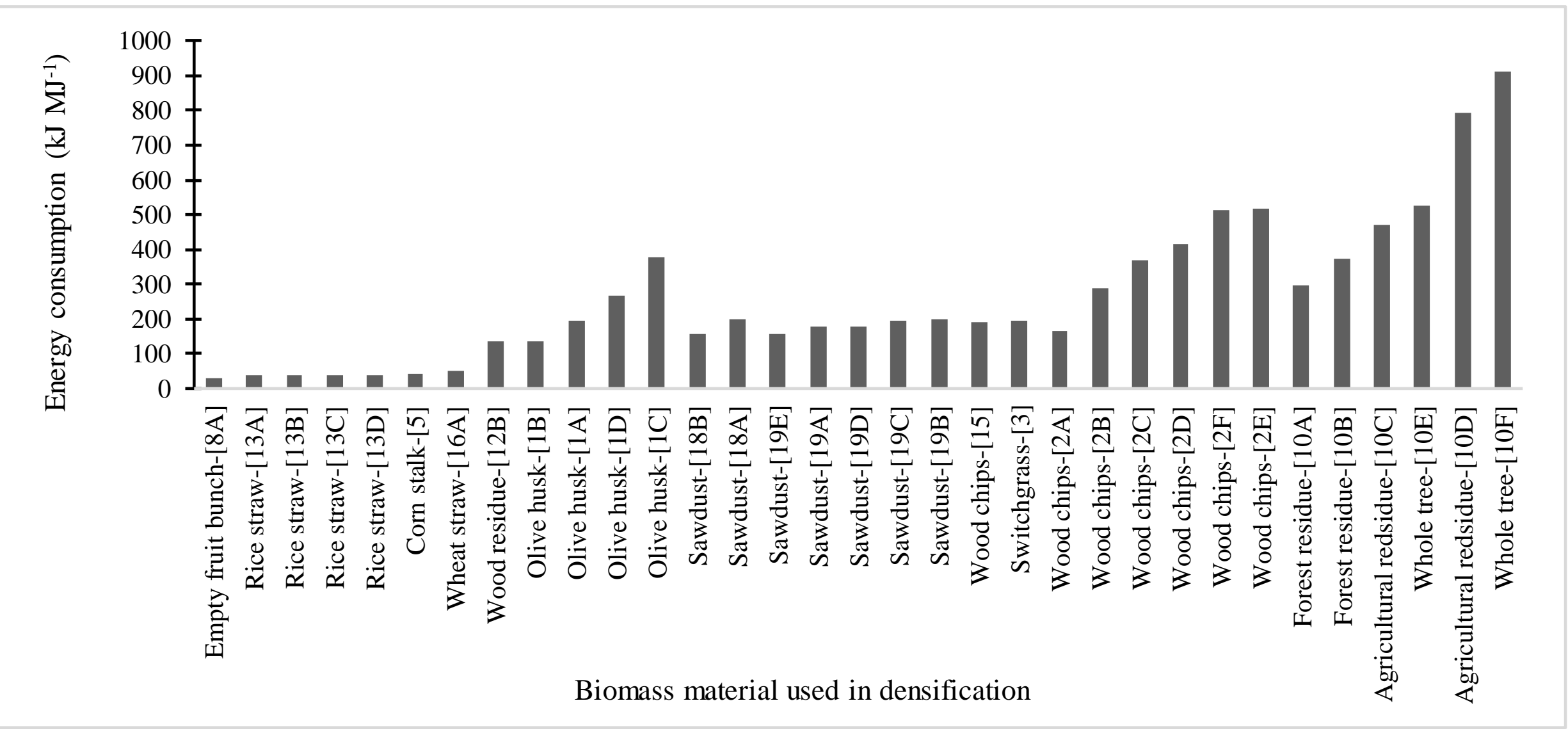




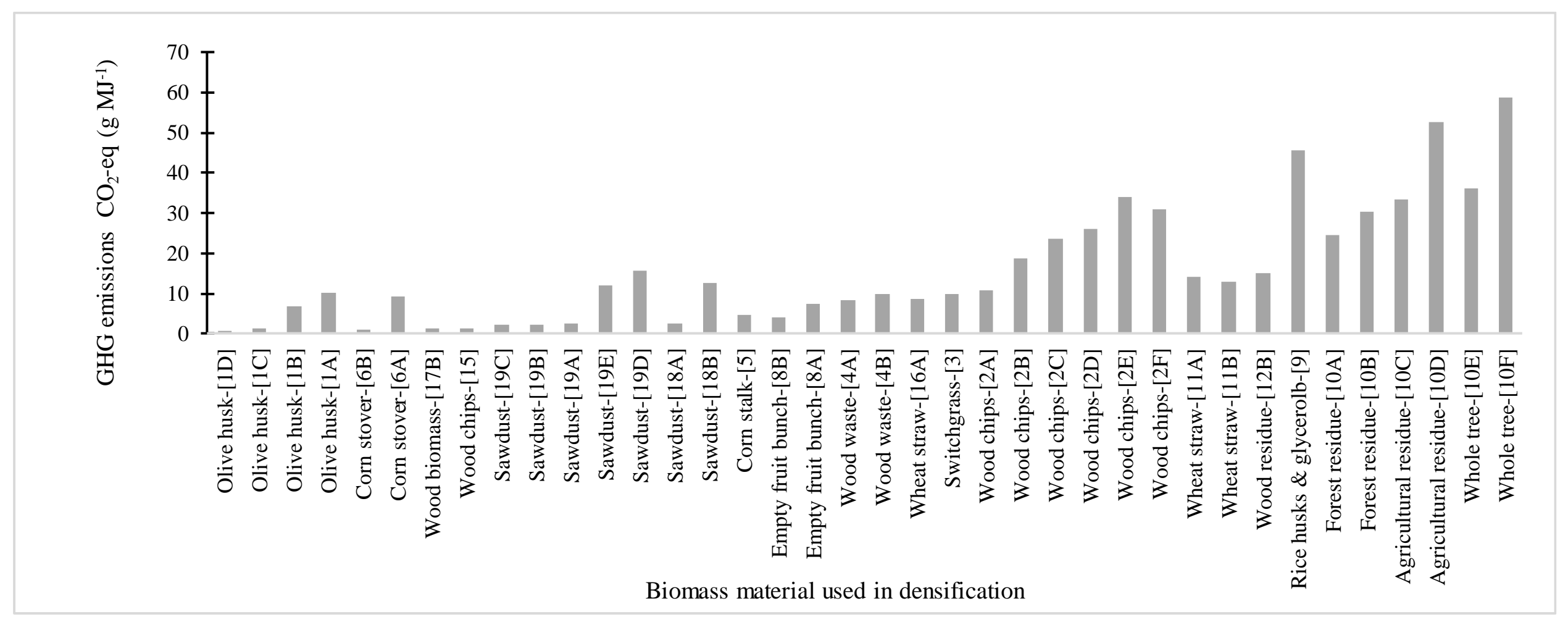




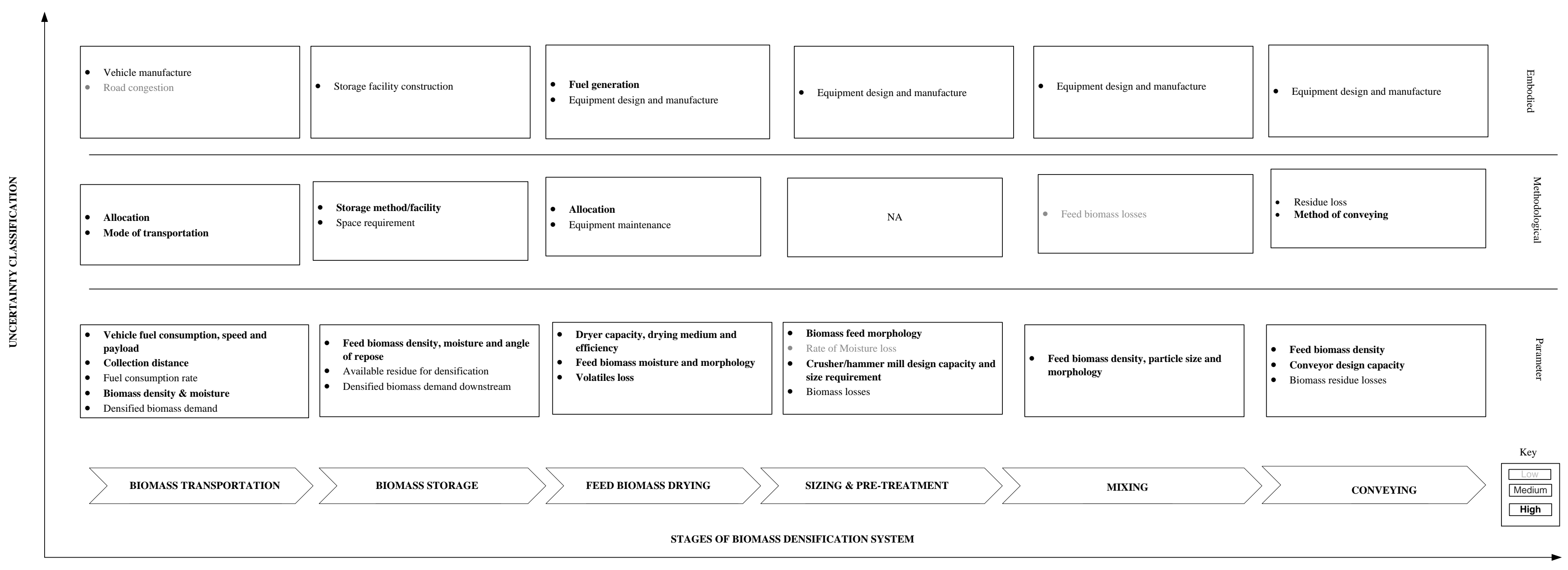




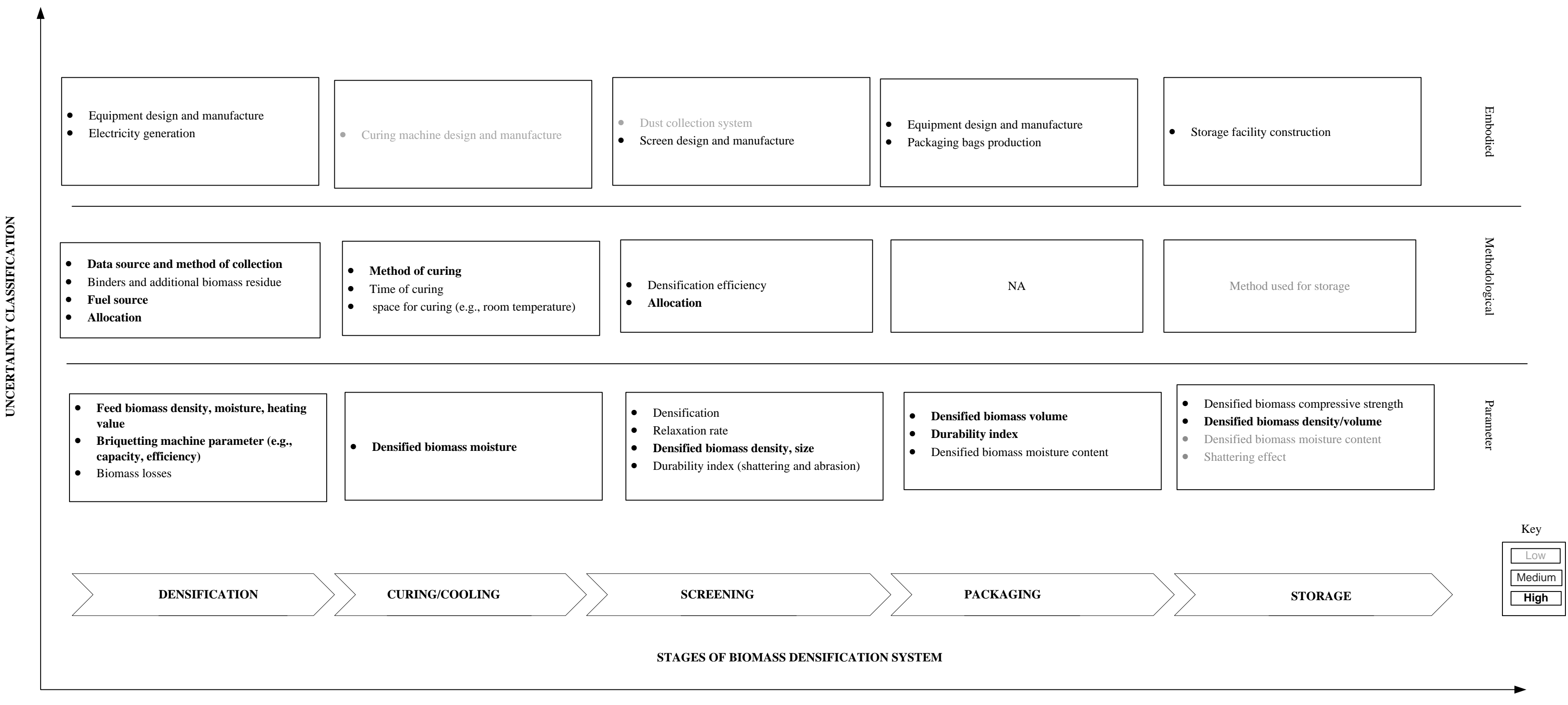


Table 1: Proportional contributions of specific biomass densification system components to energy consumption and greenhouse gas emissions (\%)

\begin{tabular}{|c|c|c|c|c|c|c|c|c|c|c|c|}
\hline Indicator & Storage & Drying & Conveying & $\begin{array}{c}\text { Size } \\
\text { reduction }\end{array}$ & Densification & Blending & $\begin{array}{l}\text { Curing/ } \\
\text { Cooling }\end{array}$ & Screening & Packaging & Transport & Reference \\
\hline \multirow{6}{*}{ 预 } & 3 & 24 & NA & 19 & 32 & NA & NA & NA & NA & $22(5.5 \mathrm{~km})^{\mathrm{d}}$ & {$[15]^{\mathrm{a}, \mathrm{b}}$} \\
\hline & 2 & 30 & NA & 36 & 9 & NA & NA & NA & NA & $23(4.6 \mathrm{~km})^{\mathrm{d}}$ & {$[15]^{\mathrm{a}, \mathrm{c}}$} \\
\hline & NA & 6 & NA & 26 & 63 & NA & 5 & NA & NA & NA & {$[12]$} \\
\hline & NA & 26 & NA & NA & 74 & NA & NA & NA & NA & NA & [19] \\
\hline & NA & 65 & NA & 11 & 24 & NA & NA & NA & NA & NA & {$[18]$} \\
\hline & 1 & 29 & 2 & 60 & 7 & NA & 1 & NA & NA & NA & {$[20]^{\mathrm{a}}$} \\
\hline \multirow{5}{*}{ 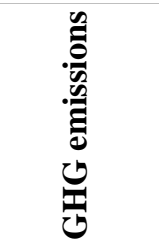 } & NA & 33 & NA & 21 & 34 & NA & 2 & NA & NA & $\mathbf{1 0}(356 \mathrm{~km})$ & {$[13]^{\mathrm{a}}$} \\
\hline & 2 & 23 & NA & 20 & 33 & NA & 1 & NA & NA & $21(5.5 \mathrm{~km})^{\mathrm{d}}$ & {$[15]^{\mathrm{a}, \mathrm{b}}$} \\
\hline & 1 & 27 & NA & 38 & 11 & NA & 1 & NA & NA & $22(4.6 \mathrm{~km})^{\mathrm{d}}$ & {$[15]^{\mathrm{a}, \mathrm{c}}$} \\
\hline & 14 & 24 & NA & NA & NA & 48 & NA & NA & 0.0002 & NA & {$[21]$} \\
\hline & $\mathrm{NA}$ & 8 & NA & NA & 92 & NA & NA & NA & NA & NA & [20] \\
\hline
\end{tabular}

a: Some values were approximated from plots provided in source

b: Torrefied pellets

c: Wood pellets

d: Distance only covers loose biomass transportation 
Table 2: Summary of previous work on life cycle assessment of biomass densification (listed in reverse order of publication date)

\begin{tabular}{|c|c|c|c|c|c|c|c|c|c|c|c|}
\hline \multirow{3}{*}{$\begin{array}{l}\text { Code in } \\
\text { Figures } \\
2 \& 3\end{array}$} & \multirow[b]{3}{*}{$\begin{array}{l}\text { Type of } \\
\text { biomass }\end{array}$} & \multirow[b]{3}{*}{ Technology } & \multirow{3}{*}{$\begin{array}{c}\text { Annual } \\
\text { Densified } \\
\text { biomass } \\
\text { output } \\
\left(\mathbf{t ~}^{-1}\right)\end{array}$} & \multirow{3}{*}{$\begin{array}{l}\text { System boundary } \\
\text { (gates as shown in } \\
\text { Figure 1) }\end{array}$} & \multirow[b]{3}{*}{ Scenario } & \multicolumn{6}{|c|}{ Results for different environmental impact indicators } \\
\hline & & & & & & \multicolumn{2}{|c|}{ Energy consumption } & \multicolumn{3}{|l|}{ GHG emissions } & \multirow[b]{2}{*}{ Reference } \\
\hline & & & & & & $\begin{array}{l}\text { Reported } \\
\text { (per functional unit) }\end{array}$ & $\begin{array}{l}\text { Normalised } \\
\quad\left(\mathbf{G J ~ t}^{-1}\right)\end{array}$ & $\begin{array}{c}\text { Reported } \\
\text { (per functional unit) }\end{array}$ & $\begin{array}{l}\text { Normalised } \\
\mathrm{CO}_{2 \cdot-\mathrm{eq}} \\
\left(\mathrm{g} \mathrm{MJ}^{-1}\right)^{\mathrm{h}}\end{array}$ & Others & \\
\hline $1 \mathrm{~A}$ & \multirow{4}{*}{ Olive husks } & \multirow{4}{*}{ Pelletizer } & \multirow{4}{*}{ NA } & \multirow{4}{*}{ gate $\mathrm{A}$-to-gate $\mathrm{D}$} & Centralised management & $4.8\left(\mathrm{MJ} \mathrm{kg}^{-1}\right)$ pellet & 4.8 & $240 \mathrm{~kg} \mathrm{t}^{-1}\left(\mathrm{CO}_{2}\right.$-eq from pellets $)$ & 11 & \multirow{4}{*}{$\mathrm{NA}$} & \multirow{4}{*}{ [13] } \\
\hline $1 \mathrm{~B}$ & & & & & \multirow{3}{*}{$\begin{array}{l}\text { Decentralised management } \\
\text { Centralised management/ } \\
\text { renewable energy } \\
\text { Decentralised management/ } \\
\text { renewable energy }\end{array}$} & $3.4\left(\mathrm{MJ} \mathrm{kg}^{-1}\right)$ pellet & 3.4 & $167 \mathrm{~kg} \mathrm{t}^{-1}\left(\mathrm{CO}_{2}\right.$-eq from pellets) & 7.5 & & \\
\hline $1 \mathrm{C}$ & & & & & & $9.4\left(\mathrm{MJ} \mathrm{kg}^{-1}\right)$ pellet & 9.4 & $35 \mathrm{~kg} \mathrm{t}^{-1}\left(\mathrm{CO}_{2}\right.$-eq from pellets) & \multirow{2}{*}{$\begin{array}{c}1.6 \\
0.72\end{array}$} & & \\
\hline $1 \mathrm{D}$ & & & & & & $6.6\left(\mathrm{MJ} \mathrm{kg}^{-1}\right)$ pellet & 6.6 & $16 \mathrm{~kg} \mathrm{t}^{-1}\left(\mathrm{CO}_{2}\right.$-eq from pellets $)$ & & & \\
\hline $2 \mathrm{~A}$ & \multirow{6}{*}{ Wood chips } & \multirow{6}{*}{ Pelletizer } & \multirow{6}{*}{$60,000 \mathrm{t}$} & \multirow{6}{*}{ cradle A -to-gate C } & \multirow{2}{*}{$3.0 \mathrm{MJ} / \mathrm{kg}$ water removed } & 5.7 oil-eq $\left(\mathrm{g} \mathrm{MJ}^{-1}\right) \mathrm{TP}$ & $5.3^{\mathrm{a}, \mathrm{e}}$ & $17.50 \mathrm{~g} \mathrm{MJ}^{-1}\left(\mathrm{CO}_{2}\right.$-eq from TP $)$ & 18 & $\begin{array}{l}47.1 \mathrm{~km}^{2} / \mathrm{y} \\
\text { land use }\end{array}$ & \multirow{6}{*}{ [15] } \\
\hline $2 \mathrm{~B}$ & & & & & & 9.8 oil-eq $\left(\mathrm{g} \mathrm{MJ}^{-1}\right) \mathrm{WP}$ & $6.4^{4, e}$ & $27.60 \mathrm{~g} \mathrm{MJ}^{-1}\left(\mathrm{CO}_{2}\right.$-eq from WP $)$ & 28 & $\begin{array}{l}45.9 \mathrm{~km}^{2} / \mathrm{y} \\
\text { land use }\end{array}$ & \\
\hline $2 \mathrm{C}$ & & & & & \multirow[b]{2}{*}{$6.0 \mathrm{MJ} / \mathrm{kg}$ water removed } & 9.5 oil-eq $\left(\mathrm{g} \mathrm{MJ}^{-1}\right) \mathrm{TP}$ & $8.8^{\mathrm{a}, \mathrm{e}}$ & $28 \mathrm{~g} \mathrm{MJ}^{-1}\left(\mathrm{CO}_{2}\right.$-eq from $\left.\mathrm{TP}\right)$ & 28 & $\begin{array}{l}47.1 \mathrm{~km}^{2} / \mathrm{y} \\
\text { land use }\end{array}$ & \\
\hline $2 \mathrm{D}$ & & & & & & 12 oil-eq $\left(\mathrm{g} \mathrm{MJ}^{-1}\right) \mathrm{WP}$ & $7.8^{\mathrm{a}, \mathrm{e}}$ & $34 \mathrm{~g} \mathrm{MJ}^{-1}\left(\mathrm{CO}_{2}\right.$-eq from WP) & 34 & $\begin{array}{l}45.9 \mathrm{~km}^{2} / \mathrm{y} \\
\text { land use }\end{array}$ & \\
\hline $2 \mathrm{E}$ & & & & & \multirow{2}{*}{$9.0 \mathrm{MJ} / \mathrm{kg}$ water removed } & 14.3 oil-eq $\left(\mathrm{g} \mathrm{MJ}^{-1}\right) \mathrm{TP}$ & $13.2^{2, e}$ & $40.02 \mathrm{~g} \mathrm{MJ}^{-1}\left(\mathrm{CO}_{2}\right.$-eq from TP $)$ & 40 & $\begin{array}{l}47.1 \mathrm{~km}^{2} / \mathrm{y} \\
\text { land use }\end{array}$ & \\
\hline $2 \mathrm{~F}$ & & & & & & $\begin{array}{c}14.7 \text { oil-eq }\left(\mathrm{g} \mathrm{MJ}^{-1}\right) \\
\text { WP }\end{array}$ & $9.5^{\mathrm{a}, \mathrm{e}}$ & $41.05 \mathrm{~g} \mathrm{MJ}^{-1}\left(\mathrm{CO}_{2}\right.$-eq from WP $)$ & 41 & $\begin{array}{l}45.9 \mathrm{~km}^{2} / \mathrm{y} \\
\text { land use }\end{array}$ & \\
\hline 3 & Switchgrass & Pelletizer & NA & cradle A -to-gate C & NA & $4.1\left(\mathrm{GJ} \mathrm{t}^{-1}\right)$ & 4.1 & $0.012 \mathrm{~kg} \mathrm{MJ}^{-1}\left(\mathrm{CO}_{2}-\mathrm{eq}\right)$ & 12 & NA & [34] \\
\hline $\begin{array}{l}4 \mathrm{~A} \\
4 \mathrm{~B}\end{array}$ & Wood waste & Pelletizer & $\begin{array}{l}60,000 \mathrm{t} \\
70,000 \mathrm{t}\end{array}$ & cradle B -to-gate C & $\begin{array}{l}\text { Torrefied pellets } \\
\text { Wood pellets }\end{array}$ & NA & NA & $\begin{array}{c}0.814 \mathrm{~kg} \mathrm{kWh}^{-1}\left(\mathrm{CO}_{2} \text {-eq from }\right. \\
\text { pellets } \\
0.81 \mathrm{~kg} \mathrm{kWh}^{-1}\left(\mathrm{CO}_{2} \text {-eq from }\right. \\
\text { pellets })\end{array}$ & $\begin{array}{l}230 \\
230\end{array}$ & NA & {$[35]$} \\
\hline 5 & Corn stalks & $\begin{array}{l}\text { Flat die } \\
\text { briquette } \\
\text { machine }\end{array}$ & $20,000 \mathrm{t}$ & gate A-to-grid & NA & $15325.9\left(\mathrm{GJ} \mathrm{y}^{-1}\right)$ & $0.77^{\mathrm{h}}$ & $323.00 \mathrm{t} \mathrm{yr}^{-1}\left(\mathrm{CO}_{2}\right.$-eq $)$ & 1.6 & $\begin{array}{c}0.0016 \mathrm{~g} \\
\mathrm{SO}_{2} \text {-eq/MJ } \\
\text { pellets } \\
\\
0.0150 \mathrm{~g} \\
\mathrm{PM} 10 / \mathrm{MJ} \\
\text { pellets }\end{array}$ & [12] \\
\hline $6 \mathrm{~A}$ & Corn stover & Pelletizer & $900,000 \mathrm{t}$ & cradle B -to-gate D & $\begin{array}{l}\text { Pelleting plants located near } \\
\text { source }\end{array}$ & NA & NA & $\begin{array}{l}41^{\mathrm{f}} \mathrm{g} \mathrm{MJ}^{-1}\left(\mathrm{CO}_{2} \text {-eq from }\right. \\
\text { ethanol) }\end{array}$ & $41^{\mathrm{e}, \mathrm{g}}$ & $\mathrm{NA}$ & [16] \\
\hline $6 \mathrm{~B}$ & & & & & $\begin{array}{l}\text { Pelleting plants located near } \\
\text { biorefinery }\end{array}$ & & & $\begin{array}{l}33^{\mathrm{f}} \mathrm{g} \mathrm{MJ}^{-1}\left(\mathrm{CO}_{2} \text {-eq from }\right. \\
\text { ethanol) }\end{array}$ & $33^{\mathrm{e}, \mathrm{g}}$ & & \\
\hline 7 & Charcoal dust & $\begin{array}{l}\text { Manual } \\
\text { operation }\end{array}$ & $4.6 \mathrm{t}^{\mathrm{b}}$ & cradle A -to-grid & NA & NA & NA & $1.6 \mathrm{~kg} 1000 \mathrm{~g} \mathrm{meal}^{-1}\left(\mathrm{CO}_{2}\right.$ eq $)$ & 65 & NA & [31] \\
\hline $8 \mathrm{~A}$ & $\begin{array}{l}\text { Empty fruit } \\
\text { bunch (EFB) }\end{array}$ & NA & 5940 & gate B-to-gate C & $\begin{array}{l}\text { Without allocation of avoided } \\
\text { products }\end{array}$ & $166\left(\mathrm{MJ} \mathrm{t}^{-1}\right) \mathrm{EFB}$ & & $43.7 \mathrm{~kg} \mathrm{t}^{-1}\left(\mathrm{CO}_{2}\right.$-eq from $\left.\mathrm{EFB}\right)$ & $7.4^{\mathrm{i}}$ & $\begin{array}{l}0.17 \mathrm{~kg} \mathrm{SO}_{2-} \\
\mathrm{eq} / \mathrm{t} \mathrm{EFB}\end{array}$ & [17] \\
\hline
\end{tabular}




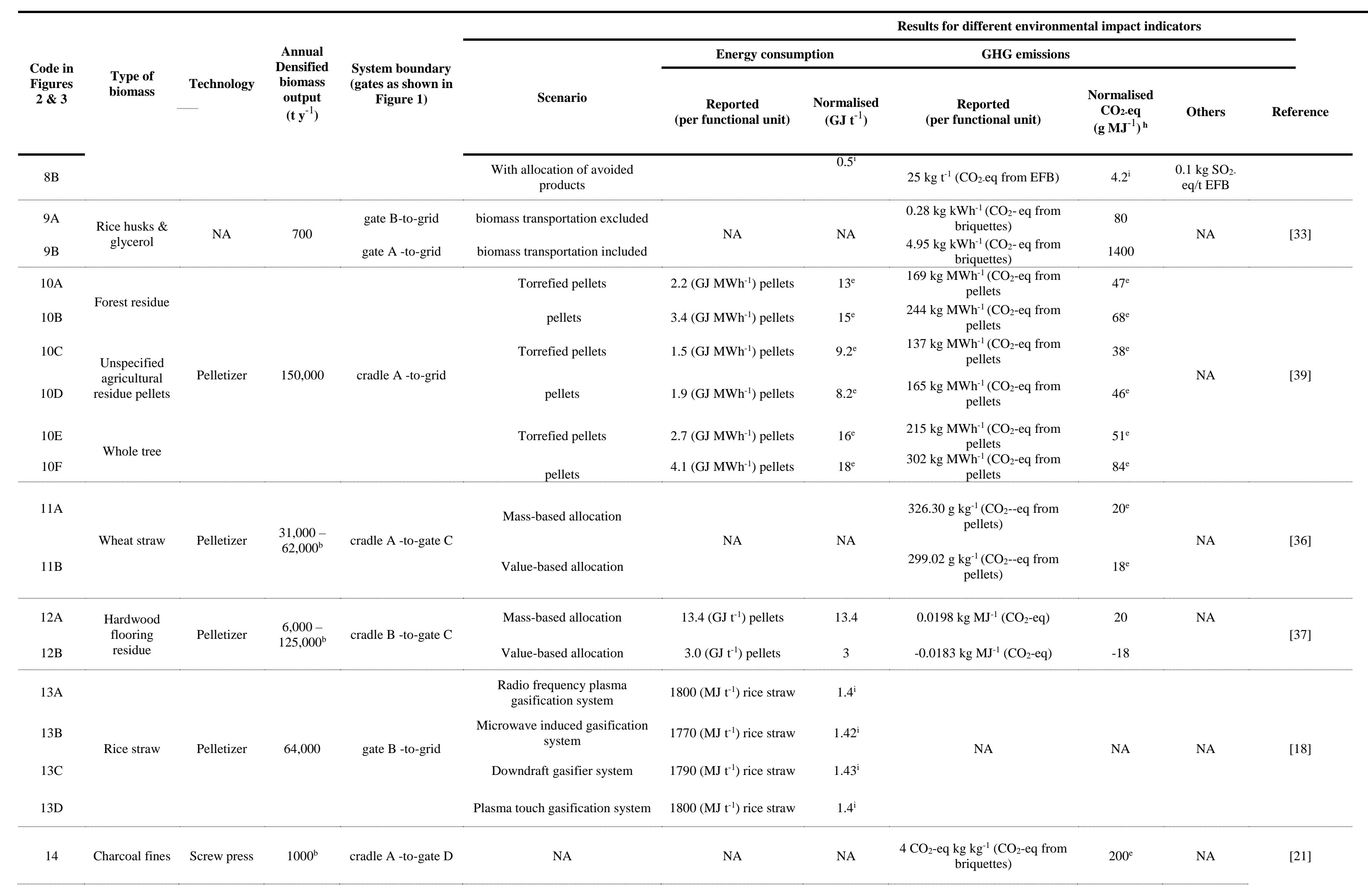




\begin{tabular}{|c|c|c|c|c|c|c|c|c|c|c|c|}
\hline \multirow{3}{*}{$\begin{array}{l}\text { Code in } \\
\text { Figures } \\
2 \& 3\end{array}$} & \multirow{3}{*}{$\begin{array}{l}\text { Type of } \\
\text { biomass }\end{array}$} & \multirow[b]{3}{*}{ Technology } & \multirow{3}{*}{$\begin{array}{c}\text { Annual } \\
\text { Densified } \\
\text { biomass } \\
\text { output } \\
\left(\mathbf{t} \mathbf{y}^{-1}\right)\end{array}$} & \multirow{3}{*}{$\begin{array}{l}\text { System boundary } \\
\text { (gates as shown in } \\
\text { Figure 1) }\end{array}$} & \multirow[b]{3}{*}{ Scenario } & \multicolumn{6}{|c|}{ Results for different environmental impact indicators } \\
\hline & & & & & & \multicolumn{2}{|c|}{ Energy consumption } & \multicolumn{2}{|l|}{ GHG emissions } & \multirow[b]{2}{*}{ Others } & \multirow[b]{2}{*}{ Reference } \\
\hline & & & & & & $\begin{array}{c}\text { Reported } \\
\text { (per functional unit) }\end{array}$ & $\begin{array}{l}\text { Normalised } \\
\quad\left(\mathbf{G J ~ t}^{-1}\right)\end{array}$ & $\begin{array}{c}\text { Reported } \\
\text { (per functional unit) }\end{array}$ & $\begin{array}{l}\text { Normalised } \\
\mathrm{CO}_{2} \cdot \mathrm{eq} \\
\left(\mathrm{g} \mathrm{MJ}^{-1}\right)^{\mathrm{h}}\end{array}$ & & \\
\hline 15 & Wood chips & NA & NA & gate B -to-grid & NA & $5000\left(\mathrm{MJ} \mathrm{t}^{-1}\right)$ briquettes & 5 & $\begin{array}{l}35.7 \mathrm{CO}_{2}-\mathrm{eq} \mathrm{kg} \mathrm{kg} \mathrm{kg}^{-1}\left(\mathrm{CO}_{2} \text {-eq }\right. \\
\text { from briquettes })\end{array}$ & 1.3 & NA & [29] \\
\hline $16 \mathrm{~A}$ & \multirow{9}{*}{ Wheat straw } & \multirow{9}{*}{ Pelletizer } & \multirow{9}{*}{150,000} & \multirow{9}{*}{ cradle A -to-grid } & Mass-based allocation (base case) & $0.29\left(\mathrm{MJ} \mathrm{MJ}^{-1}\right)$ pellets & $4.7^{\mathrm{e}}$ & $\begin{array}{l}0.031 \mathrm{~kg} \mathrm{MJ}^{-1}\left(\mathrm{CO}_{2} \text {-eq from }\right. \\
\text { pellets })\end{array}$ & $31^{\mathrm{e}}$ & \multirow{9}{*}{ NA } & \multirow{9}{*}{ [19] } \\
\hline $16 \mathrm{~B}$ & & & & & $\begin{array}{l}\text { no allocation of upstream farming } \\
\text { activities to straw }\end{array}$ & $0.15\left(\mathrm{MJ} \mathrm{MJ}^{-1}\right)$ pellets & $2.5^{\mathrm{e}}$ & $\begin{array}{l}0.02 \mathrm{~kg} \mathrm{MJ}^{-1}\left(\mathrm{CO}_{2} \text {-eq from }\right. \\
\text { pellets })\end{array}$ & $20^{\mathrm{e}}$ & & \\
\hline $16 \mathrm{C}$ & & & & & Use of organic fertilizer & $0.12\left(\mathrm{MJ} \mathrm{MJ}^{-1}\right)$ pellets & $1.9^{\mathrm{e}}$ & $\begin{array}{c}0.01 \mathrm{~kg} \mathrm{MJ}^{-1}\left(\mathrm{CO}_{2} \text {-eq from }\right. \\
\text { pellets) }\end{array}$ & $10^{\mathrm{e}}$ & & \\
\hline $16 \mathrm{D}$ & & & & & Zero tillage system & $0.27\left(\mathrm{MJ} \mathrm{MJ}^{-1}\right)$ pellets & $4.4^{\mathrm{e}}$ & $\begin{array}{l}0.027 \mathrm{~kg} \mathrm{MJ}^{-1}\left(\mathrm{CO}_{2} \text {-eq from }\right. \\
\text { pellets })\end{array}$ & $27^{\mathrm{e}}$ & & \\
\hline $16 \mathrm{E}$ & & & & & Drying with biomass energy & $0.284\left(\mathrm{MJ} \mathrm{MJ}^{-1}\right)$ pellets & $4.6^{\mathrm{e}}$ & $\begin{array}{c}0.028 \mathrm{~kg} \mathrm{MJ}^{-1}\left(\mathrm{CO}_{2} \text {-eq from }\right. \\
\text { pellets })\end{array}$ & $28^{\mathrm{e}}$ & & \\
\hline $16 \mathrm{~F}$ & & & & & Drying with natural gas & NA & NA & $\begin{array}{c}0.028 \mathrm{~kg} \mathrm{MJ}^{-1}\left(\mathrm{CO}_{2} \text {-eq from }\right. \\
\text { pellets })\end{array}$ & $28^{e}$ & & \\
\hline $16 \mathrm{G}$ & & & & & No drying & $0.281\left(\mathrm{MJ} \mathrm{MJ}^{-1}\right)$ pellets & $4.6^{\mathrm{e}}$ & $\begin{array}{c}0.027 \mathrm{~kg} \mathrm{MJ}^{-1}\left(\mathrm{CO}_{2} \text {-eq from }\right. \\
\text { pellets })\end{array}$ & $27^{\mathrm{e}}$ & & \\
\hline $16 \mathrm{H}$ & & & & & $100 \%$ truck transportation & $0.29\left(\mathrm{MJ} \mathrm{MJ}^{-1}\right)$ pellets & $4.7^{\mathrm{e}}$ & $\begin{array}{c}0.027 \mathrm{~kg} \mathrm{MJ}^{-1}\left(\mathrm{CO}_{2} \text {-eq from }\right. \\
\text { pellets })\end{array}$ & $27^{\mathrm{e}}$ & & \\
\hline $16 \mathrm{I}$ & & & & & $\begin{array}{l}\text { Mixed truck and rail } \\
\quad \text { transportation }\end{array}$ & $0.283\left(\mathrm{MJ} \mathrm{MJ}^{-1}\right)$ pellets & $4.6^{\mathrm{e}}$ & $\begin{array}{c}0.027 \mathrm{~kg} \mathrm{MJ}^{-1}\left(\mathrm{CO}_{2} \text {-eq from }\right. \\
\text { pellets })\end{array}$ & $27^{\mathrm{e}}$ & & \\
\hline $17 \mathrm{~A}$ & \multirow[b]{2}{*}{ Wood } & \multirow[b]{2}{*}{ Pelletizer } & \multirow[b]{2}{*}{$12,400^{\mathrm{b}}$} & \multirow[b]{2}{*}{ cradle A -to-grid } & EDIP & \multirow[b]{2}{*}{ NA } & \multirow[b]{2}{*}{ NA } & $2.42\left(\mu \mathrm{Pt} \mathrm{MJ}{ }^{-1}\right)$ pellets & $0.3^{\mathrm{ce} e}$ & $3.78 \mu \mathrm{Pt} \mathrm{AP}$ & \multirow[b]{2}{*}{ [20] } \\
\hline $17 \mathrm{~B}$ & & & & & Eco-indicator 99 & & & $64.4\left(\mu \mathrm{Pt} \mathrm{MJ}^{-1}\right)$ pellets & $5.7^{\mathrm{ce} e}$ & $\begin{array}{l}209.9 \mu \mathrm{Pt} \\
\mathrm{AP} \text { and EP }\end{array}$ & \\
\hline $18 \mathrm{~A}$ & \multirow[t]{2}{*}{ Sawdust } & \multirow[t]{2}{*}{ Pelletizer } & \multirow[t]{2}{*}{$670,000^{\mathrm{d}}$} & \multirow{2}{*}{ cradle B -to-gate D } & Drying with sawdust & $7.2\left(\mathrm{GJ} \mathrm{t}^{-1}\right)$ pellets & $7.2^{\mathrm{e}}$ & $532 \mathrm{~kg} \mathrm{t}^{-1}\left(\mathrm{CO}_{2}\right.$-eq from pellets $)$ & $28^{\mathrm{g}}$ & NA & \multirow[t]{2}{*}[38]{} \\
\hline $18 \mathrm{~B}$ & & & & & Drying with natural gas & $6.4\left(\mathrm{GJ} \mathrm{t}^{-1}\right)$ pellets & $6.4^{\mathrm{e}}$ & $723 \mathrm{~kg} \mathrm{t}^{-1}\left(\mathrm{CO}_{2}\right.$-eq from pellets $)$ & $39^{9}$ & NA & \\
\hline $19 \mathrm{~A}$ & \multirow{5}{*}{ Sawdust } & \multirow{5}{*}{ Pelletizer } & \multirow{5}{*}{$31,000^{\mathrm{b}}$} & & Drying with wood pellet & $3382.8\left(\mathrm{MJ} \mathrm{t}^{-1}\right)$ pellets & $3.4^{\mathrm{e}, \mathrm{h}}$ & $50 \mathrm{~kg} \mathrm{t}^{-1}\left(\mathrm{CO}_{2}\right.$-eq from pellets) & 2.6 & & \\
\hline 19B & & & & & Drying with wet sawdust & $3777.5\left(\mathrm{MJ} \mathrm{t}^{-1}\right)$ pellets & $3.8^{\mathrm{e}, \mathrm{h}}$ & $45 \mathrm{~kg} \mathrm{t}^{-1}\left(\mathrm{CO}_{2}\right.$-eq from pellets $)$ & 2.4 & & \\
\hline $19 \mathrm{C}$ & & & & gate B-to-gate C & Drying with dry sawdust & $3689.2\left(\mathrm{MJ} \mathrm{t}^{-1}\right)$ pellets & $3.7^{\mathrm{e}, \mathrm{h}}$ & $43 \mathrm{~kg} \mathrm{t}^{-1}\left(\mathrm{CO}_{2}\right.$-eq from pellets $)$ & 2.3 & NA & [40] \\
\hline 19D & & & & & Drying with coal & $3422.5\left(\mathrm{MJ} \mathrm{t}^{-1}\right)$ pellets & $3.4^{\mathrm{e}, \mathrm{h}}$ & $300 \mathrm{~kg} \mathrm{t}^{-1}\left(\mathrm{CO}_{2}\right.$-eq from pellets $)$ & 20 & & \\
\hline $19 \mathrm{E}$ & & & & & Drying with natural gas & $2973.3\left(\mathrm{MJ} \mathrm{t}^{-1}\right)$ pellets & $29^{\mathrm{e}, \mathrm{h}}$ & $230 \mathrm{~kg} \mathrm{t}^{-1}\left(\mathrm{CO}_{2}\right.$-eq from pellets $)$ & 12 & & \\
\hline $\begin{array}{l}\text { NA: N } \\
\text { AP: A } \\
\text { EP: Eu } \\
\text { a: } 1 \mathrm{~kg} \\
\text { b: } 20 \mathrm{~h} \\
\text { c: Eco } \\
\text { d: : } 2 \text { en } \\
\text { e: Hea }\end{array}$ & $\begin{array}{l}\text { available/applic } \\
\text { ification potent } \\
\text { phication poten } \\
\text { oil equivalent } \\
\text { pperating time a } \\
\text { ores }(\mu \mathrm{Pt}) \text { were } \\
\text { ied biomass out } \\
\mathrm{g} \text { values of dens }\end{array}$ & $\begin{array}{l}\text { verted to } \mathrm{CO}_{2}- \\
\text { was calculated } \\
\text { d biomass fron }\end{array}$ & $\begin{array}{l}\text { (g) using nc } \\
\text { suming that } \\
\text { viewed stu }\end{array}$ & $\begin{array}{l}\text { Canadian West Coast } \\
\text { were used in normalisa }\end{array}$ & $\begin{array}{l}4 \text { and } 8.9 \mathrm{E}-5 \text { for the EDIP and Eco-in } \\
\text { duction capacity is } \sim 2 / 3 \text { of the } 1,000 \text {, } \\
\text { o; where data were not available, equ }\end{array}$ & $\begin{array}{l}\text { ator respectively [67]. } \\
\text { t total annual Canadian } \\
\text { ent values for densified }\end{array}$ & roduc & . & & & \\
\hline
\end{tabular}


f: Upper boundary values provided in the study were used, lower boundary values resulted from the assumption of extreme low values for process components employed in model.

g: Recovery of $100 \%$ densified biomass energy content following thermal conversion was assumed.

h: Values were rounded to 2 significant figures.

i: $1 \mathrm{t}$ of $\mathrm{EFB}=0.33 \mathrm{t}$ briquettes, and $1 \mathrm{t}$ of rice straw residue $=0.8 \mathrm{t}$ briquettes 